\title{
Definition Of The Mechanical And Physical Qualities Of The Hollow Block Of 12 Centimeters, To Evaluate The Convenience Of Its Use
}

\author{
Gonzalo José Francisco Pérez-Gómez-Martinez, César Ponce-Palafox, José Manuel \\ Rosales-Mendoza, Abdiel González-Saucedo
}

\begin{abstract}
The present work aims to develop a comparison between the physical, mechanical and economic properties of hollow concrete blocks of 12 and 15 centimeters. First, the generation of quantitative information is required by means of tests, which were performed on both masonry pieces based on the Mexican Standards for Construction (NMX) according to the corresponding test. Subsequently, other tests are proposed which do not correspond to any NMX, but the realization of these is considered helpful to extend the parameters of the study, and consequently have a more complete final analysis.

With the comparison of the data obtained, the tests carried out on both hollow concrete blocks will determine a criterion that covers both their structural and economic behavior. This will help to determine and guarantee your work convenience, primarily focused on the use of these materials in the load walls for social housing.
\end{abstract}

Index Terms - Comparison, Hollow concrete blocks, Social housing, Work convenience.

\section{INTRODUCTION}

The hollow concrete block is one of the most used materials in construction today. According to Bloqueras.org (2018) the first hollow concrete block was designed by Harmon Syvanus Palmer in 1890 in the United States. After 10 years of experimentation this achievement patented its design in the year 1900. Its concrete blocks had the following measures: 8 X 10 X 30 inches, but their pieces were so heavy that they had to be lifted in place with a small crane.

Currently the materials that are used for the development of hollow concrete blocks are sand (although it is frequently omitted in the process of making the block) Portland cement and gravel. All this in a mixture that produces a light gray piece that is generally used as a structural element. You can find pieces of other colors for an apparent finish with a fine texture and a high resistance to compression.

In Mexico, the hollow concrete block has been used structurally in social housing. Mention Pérez, Cabanillas, Hinojosa and Borbón (2010, p.28) that "The block that is used

Gonzalo José Francisco Pérez-Gómez-Martinez, Sustainable Viability of the Building, Autonomous University of Coahuila / School of Architecture / Academic Body, Torreón, Coahuila, Mexico 871-720-2083 / 871-7353146.

César Ponce-Palafox, Sustainable Viability of the Building, Autonomous University of Coahuila / School of Architecture / Academic Body, Torreón, Coahuila, Mexico 871-166-0272.

José Manuel Rosales-Mendoza, Sustainable Viability of the Building, Autonomous University of Coahuila / School of Architecture / Academic Body, Torreón, Coahuila, Mexico

Abdiel Gonzalez-Saucedo, Thesis, Autonomous University of Coahuila / School of Architecture / Torreón, Coahuila, Mexico/ 871-106-0645. in Mexico is manufactured in various measures, the most common used in the construction of houses are the $15 \times 20 \times 40$ and the $12 \times 20 \times 40$ centimeters, the which present two internal hollow cavities of $10 \times 16$ and $7 \times 16$ centimeters respectively".

Since any Mexican families do not currently have enough economic power to purchase a home, they have begun to use the hollow concrete block of $12 \times 20 \times 40$ centimeters as a possible solution due to the lower cost in the market. This piece. Therefore, the objective of this research is to generate information that can support or refute its structural functioning in social housing.

\section{Methodology}

The methodology used in the research is of the correlational, quantitative and applied type. With the intention of establishing a broad comparison between the hollow concrete block of $12 \times 20 \times 40$ and $15 \times 20 \times 40$ centimeters. The application of the Mexican Standards (NMX) is contemplated, which establish the procedure for the analysis of the physico-mechanical characteristics of the pieces, in order to determine which of the two offers a greater economic, spatial and structural advantage in the construction of the social housing, without compromising the physical integrity of the users. The NMX to be applied in hollow concrete blocks of both sizes are:

The NMX-C-404-ONNCCE-2012 standard: Establishes the specifications and test methods that must be fulfilled by blocks, partitions, bricks and partition walls for structural use in buildings.

The NMX-C-082-ONNCCE-2013 standard: Establishes the specifications and test methods for the adherence that the masonry pieces must comply with.

The NMX-C-037-ONNCCE-2013 standard: Establishes the test method for the determination of the amount of water absorbed by blocks, bricks or concrete, ceramic or any other construction material.

The NMX-C-036-ONNCCE-2013 standard: Establishes the test method for the determination of the compressive strength of domestically manufactured and imported blocks, partitions, bricks, partitions, lattices and pavers.

In addition, other tests that do not have an NMX will be developed, but the convenience of having them performed, so that the analysis presents a greater detail of each of the characteristics that the hollow concrete block can present. These tests will help in this sense, to have more reference information, which would allow to have a better based 
criterion when determining the advantages of each piece (12 and 15 centimeters) in relation to its resistance, mechanical behavior and economic and temporal impact. Next, the tests that will be carried out are described:

The Compression test between the concrete block and the mortar joint (CBVSMJ-01): seeks to measure the resistance of both construction elements and determine which of them fails first or if they do it together.

The Nail Test (NT-01): seeks to determine the kilos of pressure necessary for a nail to penetrate one of the faces of the concrete block and analyze the damage it generates in the piece.

The Economic Test (ET-01): seeks to analyze the economic difference between both pieces and thus determine which of the two presents an advantage in cost over the other.

The Proof of Space Percentage (PSP-01): seeks to compare the percentage of space that will occupy the block wall of 12 and 15 centimeters.

The Performance Test (PT-01): seeks to establish the performance of the workforce, for each hollow concrete block expressed in square meters per day.

\section{RESULTS AND DISCUSSION}

The results obtained from the performance of each of the tests adjusted to an NMX, as well as the tests that do not correspond to a standard, are shown below. Because the research is a comparison, in each trial will appear two results, which correspond to each piece of concrete block (12 and 15 centimeters). The data obtained will be used later to carry out the conclusions of the work.

NMX-C-404: When analyzing the compressive strength by means of the corresponding test between the hollow concrete block of $12 \times 20 \times 40$ and that of $15 \times 20 \times 40$ centimeters, it was obtained that the first one has an average resistance of $34.71 \mathrm{~kg} / \mathrm{cm} 2$, while the second gave an average result of $70.77 \mathrm{~kg} / \mathrm{cm} 2$, which means that there is a difference of $36.06 \mathrm{~kg} / \mathrm{cm} 2$ in favor of the $15 \mathrm{~cm}$ block.

Specimens of hollow concrete blocks of 12-20-40 and 15-20-40 were obtained from a developer of social housing, this in order to analyze the quality of parts occupied against acquired in commercial block, and to determine which is superior by means of those tested. It was found that, the quality of the pieces used by the developer is higher, since the average resistance for the blocks of 15-20-40 was $79.22 \mathrm{~kg} /$ $\mathrm{cm} 2$, while those of 12-20-40 resisted an average of $56.92 \mathrm{~kg}$ $/ \mathrm{cm} 2$, that is, there is a difference of $22.3 \mathrm{~kg} / \mathrm{cm} 2$ in favor of the $15 \mathrm{~cm}$ block.

Calculating the general average between the blocks that were tested at the beginning with those extracted from the developer, it was found that the block of 12-20-40 has an average resistance of $45,813 \mathrm{~kg} / \mathrm{cm} 2$, while that of $15-20-40$ resists an average of $74,995 \mathrm{~kg} / \mathrm{cm} 2$, that is, the latter is $29,182 \mathrm{~kg} / \mathrm{cm} 2$ more resistant to compression than the first.
The following is shown as an example of the various compression tests performed on the various parts of Figure 1, which shows the test of a block of 12-20-40 centimeters extracted from the developer, which presented a resistance to the compression of 13,269 Tons, that is, the result is expressed in a total of $55,286 \mathrm{~kg} / \mathrm{cm} 2$.

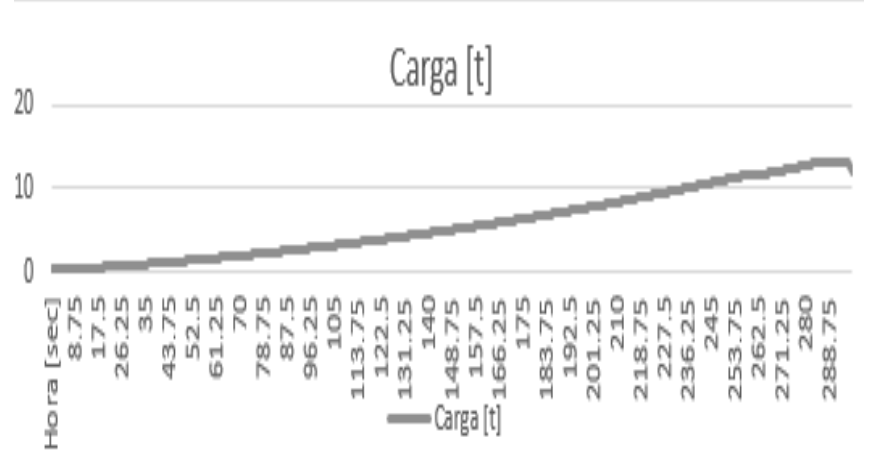

Graph 1: Test specimen compression of 12-20-40. Source: self made.

NMX-C-082: The block of 15-20-40 having a greater area of contact has consequently a lower effort to the adherence, than the block of 12 centimeters. That is to say, the lower the level of compressive strength, and the higher the value of effort to adhesion. The difference between both pieces is, for the effort of the adhesion $0.1488 \mathrm{~kg} / \mathrm{cm} 2$ against the block of $12-20-40$. For the resistance to compression it is $0.67 \mathrm{~kg} / \mathrm{cm} 2$ in favor of the $15 \mathrm{~cm}$ block.

CBVSMJ-01: The average resistances obtained are as follows: Specimen with block 12-20-40: $83.33 \mathrm{~kg} / \mathrm{cm} 2$ where both the block and the concrete joint fail simultaneously in the three specimens. While the specimen made with blocks of 15-20-40 had a resistance of $92.66 \mathrm{~kg} /$ $\mathrm{cm} 2$, and of the three specimens that were tested, the first failed the concrete block, in the second failure the board and in the third There was a simultaneous failure between the block and the board.

Next, it is shown again as an example the graph 2, which belongs to the test number three to the compression of the test of the block of 12-20-40 centimeters, against the joint of the mortar cement-sand that in proportion 1: 4 It was used, which had a compressive strength of 26,784 tons, that is: $74,399 \mathrm{~kg} /$ $\mathrm{cm} 2$.

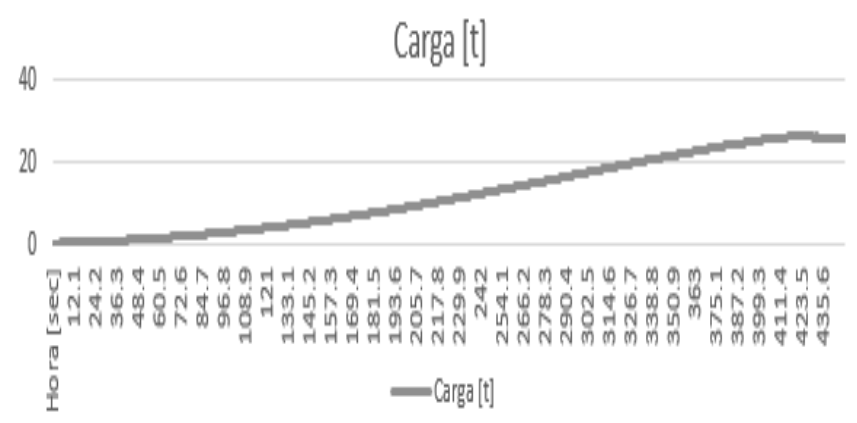

Graph 2: Joint compression test specimen of 12-20-40. Source: self-made. 
NT-01: The test already described yielded the following results, for the concrete block of 12.-20-40 466.33 kilograms of pressure are necessary, while for the 15-20-40 block, 243.66 kilograms of pressure are required, According to the above the concrete block of 12 centimeters is 222.67 kilograms of pressure more resistant than the piece of 15 centimeters, however the first one presents more damage on the surface of the block, than the one of 15-20-40.

ET-01: The use of the 12-20-40 block represents a saving per square meter of 11.88 pesos (Mexican National Currency or MNX). To analyze the difference in cost between both blocks, a social interest house located in a development of the city of Torreón, Coahuila, Mexico, was taken as a point of reference. Construction with 115 square meters of walls, which multiplied by the savings to use the block of 12-20-40 achieved a decrease of 1,366.66 MNX per house built.

PSP-01: According to the data obtained, when using the block of 12-20-40 in the construction of a house on the $15-20-40$ one could save up to $15 \%$ of the space occupied by the walls. For example, if in a house built with blocks of $15-20-40$ the walls occupy a total of $10.05 \mathrm{~m} 2$, using a block of 12-20-40, only 8.04 square meters would be occupied, thus saving 2.01 .

PT-01: The hollow concrete block of $15 \times 20 \times 40$ centimeters, has a yield of $11.00 \mathrm{M} 2$ / JO, while that of 12-20-40, being a slightly smaller and lighter piece, offers a yield of $12.00 \mathrm{M} 2$ / JO. which makes that, in terms of performance this is higher than 15-20-40. The above, affects the unit price reached by each piece.

The final comparison that contains the results of the tests carried out on both pieces, for a simpler and more practical understanding, is shown in tables 1 and 2 . In order to evaluate which is the best option for the construction of walls in social housing.

Table 1: Results of the tests of the hollow concrete block of $12 \times 20$ x 40 centimeters.

\begin{tabular}{|c|c|c|c|}
\hline $\begin{array}{c}\text { NORMA } \\
\text { APLICABLE }\end{array}$ & \multicolumn{3}{|c|}{$\begin{array}{l}\text { ESPECTMEN } \\
12 \times 20 \times 40\end{array}$} \\
\hline $\begin{array}{l}\text { NMX-C-404 } \\
\text { NMX-C-036 }\end{array}$ & $\begin{array}{c}\mathrm{KG}: \\
14.560\end{array}$ & & $\begin{array}{c}\text { KGCAD: } \\
45.813\end{array}$ \\
\hline NMD-C-082 & $\begin{array}{l}\text { TON: } \\
0.643\end{array}$ & & $\begin{array}{l}\text { SGCMD: } \\
2.679\end{array}$ \\
\hline CBVSMI-01 & $\begin{array}{l}\text { TON: } \\
29.998\end{array}$ & & $\begin{array}{l}\text { KGCMD: } \\
83.330\end{array}$ \\
\hline NMCX-C-037 & \multicolumn{3}{|c|}{$\begin{array}{c}\text { LITROS: } \\
2.333\end{array}$} \\
\hline NT-01 & \multicolumn{3}{|c|}{$\begin{array}{c}\text { KIIOGRAMOS: } \\
466.33\end{array}$} \\
\hline ET-01 & \multicolumn{3}{|c|}{$\begin{array}{c}\text { PRECIO POR MD: } \\
200.72\end{array}$} \\
\hline PSP-01 & $\begin{array}{l}\mathrm{M}: \\
0.048\end{array}$ & & $\begin{array}{l}\text { RCENTAJE: } \\
85 \%\end{array}$ \\
\hline PT-01 & \multicolumn{3}{|c|}{$12.00 \mathrm{M} / \mathrm{JO}$} \\
\hline
\end{tabular}

Table 2: Results of the tests of the hollow concrete block of $15 \times 20 \times 40$ centimeters.

\begin{tabular}{|c|c|c|c|}
\hline $\begin{array}{l}\text { NORMA } \\
\text { APLICABLE }\end{array}$ & \multicolumn{3}{|c|}{$\begin{array}{l}\text { ESPECTMEN } \\
15 \times 20 \times 40\end{array}$} \\
\hline $\begin{array}{l}\text { NMD-C-404 } \\
\text { NMD-C-036 }\end{array}$ & $\begin{array}{l}\text { KG: } \\
16.238\end{array}$ & & $\begin{array}{c}\text { KGCMD: } \\
74.995\end{array}$ \\
\hline $\mathrm{NMCX}-\mathrm{C}-082$ & 0.650 & & $\begin{array}{l}\mathrm{KGCM}: \\
3.349\end{array}$ \\
\hline CBVSMD-01 & $\begin{array}{l}\text { TON: } \\
55.593\end{array}$ & & $\begin{array}{l}\mathrm{KGCMD}: \\
92.660\end{array}$ \\
\hline $\mathrm{NMCX}-\mathrm{C}-037$ & \multicolumn{3}{|c|}{$\begin{array}{c}\text { LITROS: } \\
1.766\end{array}$} \\
\hline NT-01 & \multicolumn{3}{|c|}{$\begin{array}{c}\text { KILOGRAMOS: } \\
243.66\end{array}$} \\
\hline ET-01 & \multicolumn{3}{|c|}{$\begin{array}{c}\text { PRECIO POR MD: } \\
212.60\end{array}$} \\
\hline PSP-01 & $\begin{array}{l}\mathrm{MQ}: \\
0.060\end{array}$ & & $\begin{array}{l}\text { RCENTASE: } \\
100 \%\end{array}$ \\
\hline PT-01 & \multicolumn{3}{|c|}{$11.00 \mathrm{MD} / \mathrm{JO}$} \\
\hline
\end{tabular}

\section{CONCLUSION}

The block of 12-20-40 presents advantages in the price, the percentage of occupation of the space and in the performance of the piece, although it is clear that these advantages over the 15-20-40 are not so considerable and can be considered as not enough if it does not guarantee adequate structural work.

The block of $15 \times 20 \times 40$ centimeters, has a great advantage over the $12 \times 20 \times 40$ centimeters in each of the tests of compressive strength, adhesion, drilling test, and water absorption. In this way it can be concluded that the hollow concrete block of 15-20-40 has more qualities for its structural use than the 12-20-40, the latter being less recommendable due to its resistance capacity.

It is important to know that, although currently the $12-20-40$ block is apparently displacing the 15-20-40 block of social housing because it has a lower cost, the difference between the strength of both pieces is almost double in favor of the hollow concrete block of $15 \times 20 \times 40$ centimeters. As a hypothesis of this research, it was believed that the 12-20-40 block could be suitable for the structural work of the load-bearing walls in social housing. However, because this does not have the resistance established by the NMX-C-404 standard for masonry pieces for structural use, the hypothesis turned out to be false.

Regarding the expected scope of the present comparison, it could be said that it was fulfilled with the expected, since an analysis was generated between both blocks, and it was determined that the $12 \times 20 \times 40$ centimeters is not appropriate to be used structurally in the social housing. In addition, the strength of the block cannot guarantee a correct structural operation because it does not comply with the resistance required by the corresponding standards. Thus, it can be said that the block of 12-20-40 should not replace the concrete block of 15-20-40, in the construction of economic, popular and traditional housing.

\section{REFERENCES}

[1] Bloqueras.org. (2018). Historia de los bloques de concreto. De Bloqueras.org Sitio web: https://bloqueras.org/bloques-concreto/\# México.

[2] Pérez, Jesús B.; Cabanillas Rafael E.; Hinojosa Jesús F.; Borbón, Ana C. (2010). Estudio Numérico de la Resistencia Térmica en Muros de Bloques de Concreto Hueco con Aislamiento Térmico. Información tecnológica, 22(3), 27-38. 
Definition Of The Mechanical And Physical Qualities Of The Hollow Block Of 12 Centimeters, To Evaluate The Convenience Of Its Use

[3] Pérez Gómez Martínez G. J. F. (2018). Block of 12 centimeters. Personal comment. Mexico.

[4] NMX-C-486-ONNCCE-2014 (2014). Organismo Nacional de Normalización y Certificación de la Construcción y la Edificación. México.

[5] NMX-C-404-ONNCCE-2012 (2012). Organismo Nacional de Normalización y Certificación de la Construcción y la Edificación. México.

[6] NMX-C-111-ONNCCE-2004 (2004). Organismo Nacional de Normalización y Certificación de la Construcción y la Edificación. México.

[7] NMX-C-037-ONNCCE-2013 (2013). Organismo Nacional de Normalización y Certificación de la Construcción y la Edificación. México.

[8] NMX-C-036-ONNCCE-2013 (2013). Organismo Nacional de Normalización y Certificación de la Construcción y la Edificación. México.

[9] Ortiz Arrañaga, A. I. (2016). Comparación de propiedades físicas y mecánicas de morteros para la unión de block de concreto hecho en la zona metropolitana de la laguna, para definir su conveniencia de trabajo. Escuela de Arquitectura U.T. Tesis para obtener el título de arquitecta. México.

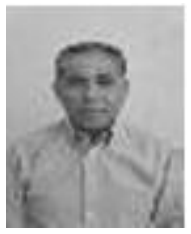

Pérez-Gómez-Martínez, Gonzalo José Francisco. Master of Science in Civil Engineering, PhD student in Civil Engineering Sciences, professor-researcher, 13 publications, 14 research projects.

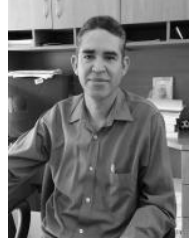

Ponce-Palafox, César. $\mathrm{PhD}$ in Sciences in Civil Engineering, professor-researcher, 15 publications, 4 research projects.

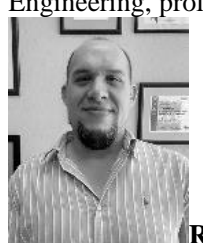

Rosales-Mendoza, José Manuel. Architect with $\mathrm{PhD}$ in History, professor-researcher, 16 publications, and 1 research project.

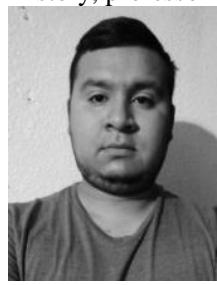

Gonzalez-Saucedo, Abdiel. Student-Thesis of the degree in architecture, article published on performance of labor. 